\section{Reference Laboratory Investigation of Patients with Clinically Diagnosed Lyme Disease and Babesiosis — Indiana, 2016}

Jennifer A. Brown, DVM ${ }^{1}$; Rex Allman, MD²; Barbara L. Herwaldt, $\mathrm{MD}^{3}$; Elizabeth Gray, $\mathrm{MPH}^{3}$; Hilda N. Rivera ${ }^{3}$; Yvonne Qvarnstrom, $\mathrm{PhD}^{3}$; Natalie Kwit, DVM ${ }^{4}$; Martin E. Schriefer, $\mathrm{PhD}^{4}$; Alison Hinckley, $\mathrm{PhD}^{4}$; Pamela Pontones, $\mathrm{MA}^{1}$

In the midwestern United States, the principal vector for Lyme disease (Borrelia burgdorferi) and babesiosis (Babesia microti) is the Ixodes scapularis tick, which has been documented in 77 of 92 Indiana counties (Indiana State Department of Health [ISDH], unpublished data, 2018) (1). The average annual Lyme disease incidence in Indiana is low (1.3 cases per 100,000 population during 2011-2015) (2); however, rates in some northwestern counties are higher (3). A two-tiered serologic testing algorithm is recommended for diagnosing Lyme disease (4). Babesiosis is rare in Indiana, with no confirmed cases and one probable case reported during 2011-2015. Blood smear examination or polymerase chain reaction (PCR) analysis are typically recommended for the diagnosis of acute babesiosis (5). In June 2016, a physician in northwestern Indiana informed ISDH of a high prevalence of clinically diagnosed Lyme disease among his patients. He further reported that eight patients evaluated during 2015-2016 had tested positive for $B$. microti immunoglobulin $\mathrm{G}(\mathrm{IgG})$ or immunoglobulin $\mathrm{M}$ (IgM) antibodies by enzyme immunoassay (EIA) at a commercial laboratory. To further evaluate these findings, ISDH and CDC conducted a laboratory investigation using specimens from some of the patients.

The physician in northwestern Indiana was asked to select clinically representative patients for further investigation; 14 were chosen, including five of the eight who had positive B. microti EIA results (Table). Whole blood and serum specimens were collected and tested at CDC for evidence of Borrelia and Babesia infection. ISDH did not conduct patient interviews or chart reviews; demographic and clinical data were obtained from the CDC specimen submission form. Clinical manifestations reported in an unstructured memo field were compared with national surveillance case definition clinical criteria for Lyme disease and babesiosis (6). CDC tested for Lyme disease by whole cell sonicate and C6 peptide EIAs followed by IgM and IgG immunoblots for all patients and for Babesia infection by examination of Giemsa-stained blood smears, PCR, and indirect fluorescent antibody (IFA) for total immunoglobulin to $B$. microti.
The 14 patients lived in seven northwestern Indiana counties. The median age was 46 years (range $=10-76$ years); nine were female (Table). The only reported objective clinical manifestations potentially consistent with Lyme disease were unspecified rashes in three patients $(\mathrm{B}, \mathrm{K}$, and $\mathrm{N})$. Objective manifestations consistent with babesiosis included anemia (patient E) and fever (patient F). A median of three prescribed antimicrobial agents (range $=1-6$ ) were reported per patient, without mention of indications. Exposure and travel histories were not provided.

Patient specimens were collected a median of 172 days (range $=22-348$ days) after reported illness onset dates; the interval was $\geq 3$ months for all but two patients (D and $G$ ). One patient $(\mathrm{M})$ had positive C6 peptide EIA results; no patient had positive whole cell sonicate EIA or immunoblot results (Table). All patient serologies were therefore interpreted to be negative for Lyme disease (4). Two patients (F and G) had B. microti IFA titers of 1:64; they reportedly became symptomatic in July 2015 and June 2016, respectively. The results of all other Babesia testing were negative.

This laboratory-based investigation does not suggest a cluster of Lyme disease or babesiosis cases among these patients. None had serologic evidence of Lyme disease or parasitologic or molecular evidence of Babesia infection, and only two had serologic evidence of $B$. microti infection. A B. microti IFA titer of 1:64 is insufficient laboratory evidence to fulfill the national surveillance case definition for non-transfusion-associated babesiosis $(\sigma)$ and could reflect early, chronic, or resolved infection or nonspecific reactivity.

Lyme disease and babesiosis should be considered in the differential diagnosis for patients with clinically compatible illness and potential exposure to I. scapularis ticks in areas where the pathogens are present. Physicians in low-prevalence states can increase the positive predictive value of laboratory testing by carefully selecting patients for testing, following established diagnostic recommendations, and using certified or accredited laboratories $(5,7)$.

Corresponding author: Jennifer A. Brown, jenbrown@isdh.in.gov, 317-233-7272.

\footnotetext{
${ }^{1}$ Indiana State Department of Health; ${ }^{2}$ Pulaski County Health Department, Winamac, Indiana; ${ }^{3}$ Division of Parasitic Diseases and Malaria, Center for Global Health, CDC; ${ }^{4}$ Division of Vector-Borne Diseases, National Center for Emerging and Zoonotic Infectious Diseases, CDC.

All authors have completed and submitted the ICMJE form for disclosure of potential conflicts of interest. No potential conflicts of interest were disclosed.
} 
TABLE. Demographic data, illness onset dates, selected clinical manifestations, and selected laboratory results for 14 patients with clinically diagnosed Lyme disease and babesiosis — Indiana, 2016

\begin{tabular}{|c|c|c|c|c|c|c|c|c|c|c|c|}
\hline \multirow[b]{3}{*}{ Patient } & \multirow[b]{3}{*}{$\begin{array}{l}\text { Age } \\
\text { (yrs) }\end{array}$} & \multirow[b]{3}{*}{ Sex } & \multirow[b]{3}{*}{$\begin{array}{l}\text { Onset } \\
\text { date }\end{array}$} & \multicolumn{2}{|c|}{ Clinical manifestation } & \multicolumn{2}{|c|}{$\begin{array}{c}\text { Babesia microti } \\
\text { serology (commercial } \\
\text { laboratory EIA) } \\
\end{array}$} & \multicolumn{4}{|c|}{ CDC results } \\
\hline & & & & \multirow[b]{2}{*}{ Objective } & \multirow[b]{2}{*}{ Subjective } & \multirow[b]{2}{*}{$\lg G$} & \multirow[b]{2}{*}{$\lg M$} & \multicolumn{3}{|c|}{ Lyme disease serology } & \multirow{2}{*}{$\begin{array}{l}\text { Total lg titer } \\
\text { to B. microti } \\
\text { (IFA)* }\end{array}$} \\
\hline & & & & & & & & $\begin{array}{l}\text { WCS } \\
\text { EIA }\end{array}$ & $\begin{array}{l}\text { C6 peptide } \\
\text { EIA }\end{array}$ & $\begin{array}{c}\lg M / \operatorname{lgG} \\
\text { immunoblot }\end{array}$ & \\
\hline A & 57 & $\mathrm{~F}$ & $09 / 2015$ & None & $\begin{array}{l}\text { Sweats, headache, } \\
\text { myalgia }\end{array}$ & pos & neg & neg & neg & neg & $<1: 8$ \\
\hline B & 50 & $\mathrm{~F}$ & $09 / 2015$ & $\operatorname{Rash}^{\dagger}$ & $\begin{array}{l}\text { Sweats, headache, } \\
\text { myalgia }\end{array}$ & pos & neg & neg & neg & neg & $<1: 8$ \\
\hline C & 31 & $\mathrm{~F}$ & $11 / 2015$ & None & Headache, myalgia & pos & neg & neg & neg & neg & $<1: 8$ \\
\hline D & 46 & M & $06 / 2016$ & None & Sweats & pos & neg & neg & neg & neg & $<1: 8$ \\
\hline $\mathrm{E}$ & 68 & $\mathrm{~F}$ & $08 / 2015$ & Anemia $^{\dagger}$ & $\begin{array}{l}\text { Sweats, headache, } \\
\text { myalgia }\end{array}$ & neg & pos & neg & neg & neg & $<1: 8$ \\
\hline $\mathrm{F}$ & 51 & $\mathrm{~F}$ & $07 / 2015$ & Fever $^{\dagger}$ & $\begin{array}{l}\text { Headache, myalgia, } \\
\text { arthralgia }\end{array}$ & $-\S$ & $-\S$ & neg & neg & neg & $1: 64$ \\
\hline G & 50 & M & $06 / 2016$ & None & $\begin{array}{l}\text { Sweats, myalgia, } \\
\text { arthralgia }\end{array}$ & - & - & neg & neg & neg & $1: 64$ \\
\hline $\mathrm{H}$ & 76 & $\mathrm{~F}$ & $07 / 2015$ & None & $\begin{array}{l}\text { Sweats, myalgia, } \\
\text { arthralgia }\end{array}$ & - & - & neg & neg & neg & $<1: 8$ \\
\hline I & 31 & M & $01 / 2016$ & None & $\begin{array}{l}\text { Sweats, myalgia, } \\
\text { arthralgia }\end{array}$ & - & - & neg & neg & neg & $<1: 8$ \\
\hline J & 40 & $\mathrm{~F}$ & $01 / 2016$ & None & Myalgia, arthralgia & - & - & neg & neg & neg & $<1: 8$ \\
\hline K & 43 & $\mathrm{~F}$ & $01 / 2016$ & $\operatorname{Rash}^{\dagger}$ & $\begin{array}{l}\text { Headache, myalgia, } \\
\text { arthralgia }\end{array}$ & - & - & neg & neg & neg & $<1: 8$ \\
\hline L & 30 & $\mathrm{~F}$ & $01 / 2016$ & NP & NP & - & - & neg & neg & neg & $<1: 8$ \\
\hline M & 45 & M & $03 / 2016$ & None & Sweats, myalgia & - & - & neg & pos & neg & $<1: 8$ \\
\hline $\mathrm{N}$ & 10 & M & $04 / 2016$ & $\operatorname{Rash}^{\dagger}$ & Myalgia & - & - & neg & neg & neg & $<1: 8$ \\
\hline
\end{tabular}

Abbreviations: $\mathrm{EIA}=$ enzyme immunoassay; $\mathrm{F}=$ female; IFA = indirect fluorescent antibody; Ig = immunoglobulin; IgG = immunoglobulin $\mathrm{G}$; IgM = immunoglobulin $M ; M=$ male; neg = negative; $N P=$ not provided; pos = positive; $W C S=$ whole cell sonicate.

* For patients $A-E$, the specimens tested by IFA were collected a median of 282 days (range $=30-323$ days) after the specimens tested by EIA.

Details not specified.

$\S$ Not done.

\section{References}

1. Eisen RJ, Eisen L, Beard CB. County-scale distribution of Ixodes scapularis and Ixodes pacificus (Acari: Ixodidae) in the continental United States. J Med Entomol 2016;53:349-86. https://doi.org/10.1093/jme/tjv237

2. Schwartz AM, Hinckley AF, Mead PS, Hook SA, Kugeler KJ. Surveillance for Lyme disease-United States, 2008-2015. MMWR Surveill Summ 2017;66(No. SS-22). https://doi.org/10.15585/mmwr.ss6622a1

3. Indiana State Department of Health. 2015 annual report of infectious diseases. Indianapolis, IN: Indiana State Department of Health; 2016. https://www.in.gov/isdh/27287.htm

4. CDC. Two-tiered testing for Lyme disease. Atlanta, GA: US Department of Health and Human Services, CDC; 2011. https://www.cdc.gov/lyme/ healthcare/clinician_twotier.html
5. Wormser GP, Dattwyler RJ, Shapiro ED, et al. The clinical assessment, treatment, and prevention of Lyme disease, human granulocytic anaplasmosis, and babesiosis: clinical practice guidelines by the Infectious Diseases Society of America. Clin Infect Dis 2006;43:1089-134. https:// doi.org/10.1086/508667

6. CDC. Surveillance case definitions for current and historical conditions. Atlanta, GA: US Department of Health and Human Services, CDC; 2017. https://wwwn.cdc.gov/nndss/conditions

7. Sanchez E, Vannier E, Wormser GP, Hu LT. Diagnosis, treatment, and prevention of Lyme disease, human granulocytic anaplasmosis, and babesiosis: a review. JAMA 2016;315:1767-77. https://doi.org/10.1001/ jama.2016.2884 